Journal of Social Sciences (COES\&RJ-JSS)

ISSN (E): 2305-9249 ISSN (P): 2305-9494

Publisher: Centre of Excellence for Scientific \& Research Journalism, COES\&RJ LLC

Online Publication Date: $1^{\text {st }}$ January 2016

Online Issue: Volume 5, Number 1, January 2016

http://www.centreofexcellence.net/J/JSS/JSS Mainpage.htm

\title{
Levels of poverty and human development index in Mexico: The state of the art of effective Social Policy (1990-2010)
}

\author{
Dr. Oscar González Muñoz ${ }^{1}$
}

Academic-Researcher; IIESCA-Universidad Veracruzana; México;

Email: oscgonzalez@uv.mx; oscargomu@yahoo.com

\begin{abstract}
:
Understand the term poverty is concerned; it is to identify the level of conditions expressing conditions deficiencies in the population. By analyzing what is required in principle, social theory developed which establishes the first signs of which represents a level of insecurity and its impact on social development. This will generate appropriate to the nature of the state public policies, social vocation which allows you know the effectiveness of existing policies.
\end{abstract}

Keywords:

food poverty, skills, assets, income.

Citation:

Muñoz, Dr. Oscar (2016); Levels of poverty and human development index in Mexico: The state of the art of effective Social Policy (1990-2010); Journal of Social Sciences (COES\&RJ-JSS), Vol.5, No.1, pp: 1-8.

${ }^{1}$ Académico Investigador del Instituto de Investigaciones y Estudios Superiores de las Ciencias Administrativas (IIESCA) de la Universidad Veracruzana.

Email: oscargomu@yahoo.com

This work is licensed under a Creative Commons Attribution 4.0 International License. 


\section{INTRODUCTION}

It needs associating with achieving physical efficiency; Maslow (1943) considered that the attention to the shortcomings is achieved within the hierarchical structure Starting with those needs that represent gaps in the order of the biological and amount to other levels of dissatisfaction within individual needs. So recognize the provisions of Maslow (1943) and relate to Marxist doctrine, -from the understanding of poverty derivative obtained-income conditions, involves considering the payment of wages is the necessary means to address gaps minimum welfare. Therefore, identifying the number of poor, lies in the evaluation of individual skills to generate income that allows consuming goods in acceptable amounts and in certain environments; starting with those of elementary order as biological.

\section{TOWARDS AN UNDERSTANDING OF THE CONCEPT OF PUBLIC POLICY IN WAITING}

Townsend (1979) understood poverty as a situation in which there are those who live at home from available media that do not allow you to access the types of socially usual diets or at least widely promoted or approved in the societies they belong. Although in 1979, Townsend caught only considered sufficient for media access satisfactions in terms of social perceptions -alejadas formal questioning of anthropological science, managed to replace the minimum needs, nutritional needs through stipends. And results in the economic order, the nutritional value of a basic food basket (CBA), as regards the minimum level of resources needed to get.

Parker (2007), (2001) and Gonzalez (2014) identifies eleven possible ways of interpreting poverty: need, standard of living, inadequate resources, lack of basic security, lack of resources and entitlements, multiple deprivation, exclusion, inequality, class, dependency and unacceptable suffering. However, the concept of poverty has been linked to a condition of minimum social welfare where a healthy and appropriate to the social life is necessary to understand the number of people living in deprivation.

\section{POVERTY IN MEXICO AND ITS RELATIONSHIP WITH THE LEVEL OF GAPS}

In Mexico, studies on the number of people in poverty in the period from 2000 to 2014, developed by Hernández-Laos (2010) to the National Council for Evaluation of Social Policy (CONEVAL), analyze the income level of the population and their ability to demand certain resources, starting with the definition of the CBA for rural and urban areas. That is, by the known method as Poverty Lines (LP) the number of poor is determined, from a macroeconomic view. Considering the access to the Basic Food Baskets (BFB) and the corresponding income poverty thresholds expressed.

Starting with determination enough to access a CBA income, food LP is created. After this, it identifies the following LP or level of income needed to build capacity, and provides insight into the level of adequate resources to access a CBA, including spending levels needed to access health and education satisfactions, creating the LP capabilities. And finally, through the income necessary to meet a CBA adding health services, education and the generation of resources that benefit the earned income, the LP wealth is generated.

Establishing the need to consume a CHAVA income, LP later determined, and therefore the need for family income to meet other basic needs after. This allows assist poverty studies from other instruments such as the Engel coefficient (EC), which establishes the 
proportion which represents another CBA. Defined as $\mathrm{CE}=\mathrm{CBA} / \mathrm{CB}$, it shows the capabilities of a CBA consumption, given the level of income needed later of a CB. And in the same way, is the Engel Coefficient Inverse (ICE), as the ratio that expresses the ability to absorb the basic assets of the CBA, with income necessary for later $\mathrm{CB}$ including the CBA to other goods no food; raised as $\mathrm{ICE}=\mathrm{CB} / \mathrm{CBA}$, the number of times you can eat a CBA, in terms of a $\mathrm{CB}$ is evident. Therefore, the study of poverty in Mexico (part of a classical view), which considers the income as the instrument to count the number of poor by the LP. Starting with the capacity to buy a CBA through ICE, as the factor that shows the ability of income to earned a CB. Thus, in Mexico it has decreased specifically between the regions which in the year 1990 had the highest levels of food poverty at national level. See Figure No.1.

Sex Figure No, 1

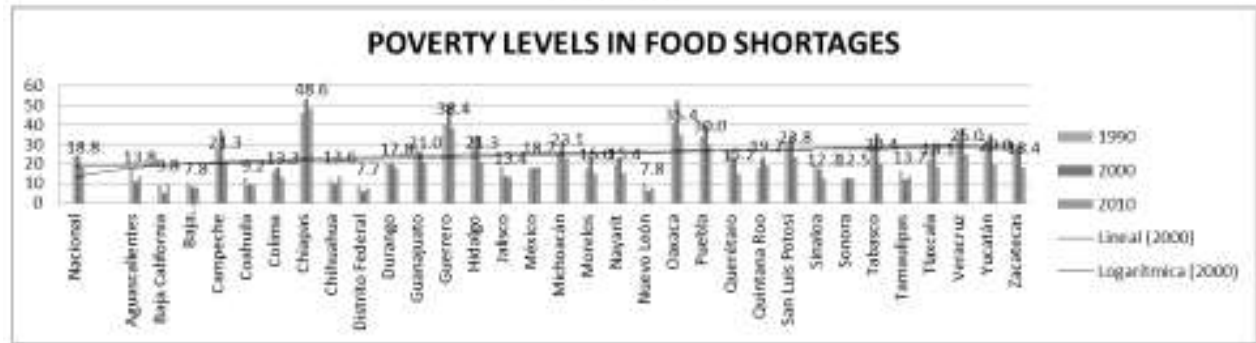

Data Source: Prepared by the INEGI database (1990-2014)

However, the poverty level in food shortages means a major challenge and is associated with a great social inequality where deprivation and lack of access to basic goods and services contribute to the exacerbation of conditions of equality. ECLAC (2014th) and ECLAC (2014b) within which are also social and contextual nature not only economic, but also lead to poverty study from an interdisciplinary vision that explain this condition holistically. See figure \#2.

See Finge 12

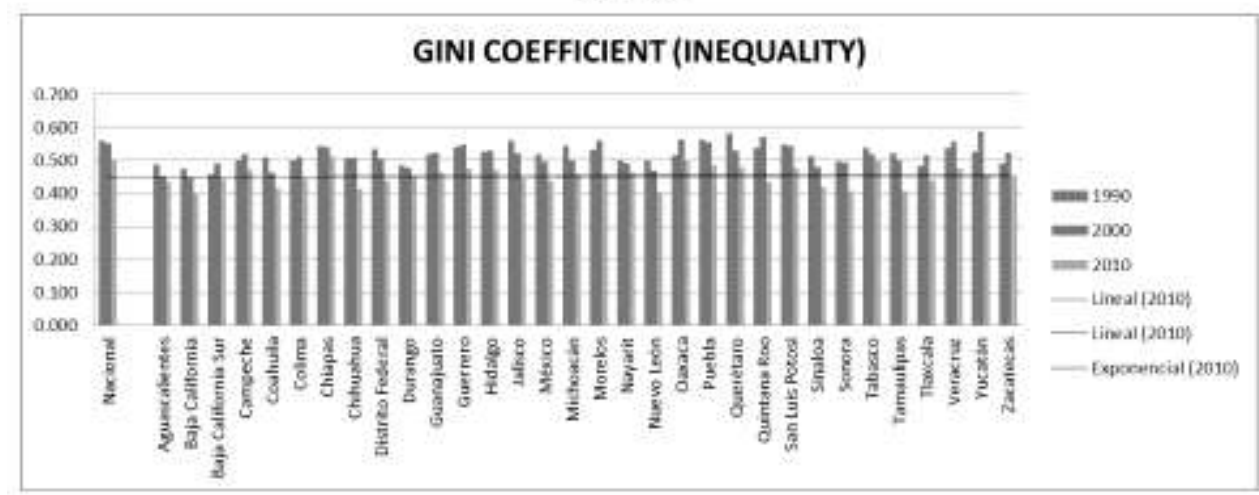

Data Source: Prepared by the INEGI database (1990-2014)

So, the poverty levels and its measurement capabilities in the context of Mexico, has other dimensions, such as human capacity-especially education and health-situation, the poverty of capabilities identified among the population with access to infrastructure, health services and education as a means of reducing social exclusion. Therefore conceivable the 
capability poverty level based on the recognition of multiple dimensions that relate to the lack of sufficient means to create conditions of equality and legitimacy to the consumption of basic resources. Through an imperfect approach, Sen (1992) and Sen (2000) refers to poverty through welfare levels in terms of freedom (or capacity) of a person to choose his life. This depends on their human capacities and their ability to turn them into "beings and doings".

The Poverty levels in Mexico, has reduced capacity in some regions; the problem of the lack of economic stability and public services to ensure the development of skills among the population as a means to poverty reduction, has been unstable and lacking in effectiveness. However, under legal protection of individual rights and institutional since 2002 (with the institutionalization of the General Law of Social Development) mechanisms and later as programs aimed at the reduction of poverty as ProgresaOportunidades-Prospera, reducing poverty levels has been effective capacity.

Starting with determination enough to access a CBA income, food LP is created. After this, it identifies the following LP or level of income needed to build capacity, and provides insight into the level of adequate resources to access a CBA, including the expenditures necessary to access health and education satisfactions, creating an LP capability. See in Figure \#3. And with that, the growth levels based on capacity development for the regions of Mexico poverty. That is, the level of growth of the shortcomings related to the instrumental capabilities of productive organization is limited to its reduction.
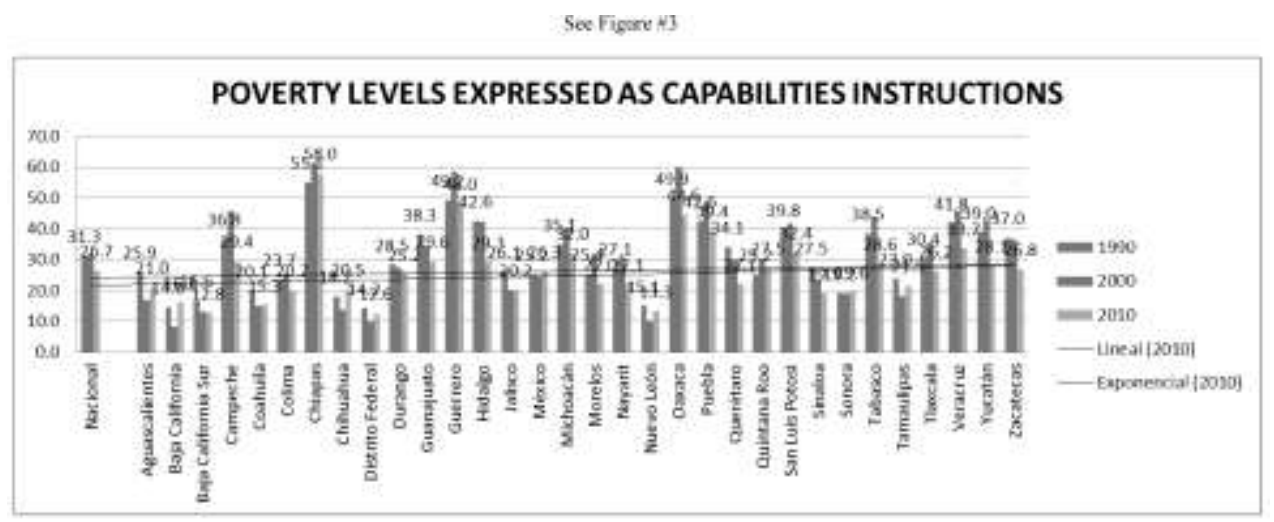

Data Source: Prepared by the INEGI database (1990-2014)

According to the modern theory of poverty headed by Sen (1978), with reference to the Universal Declaration of Human Rights (1948), the limited amount of goods that denote poverty, and capabilities to allow restricted access to basic needs such as one CBA, not achieved only through essentially economic conditions such as income and employment. Other factors such as ideology, personality, values and individual freedoms, which recognizes as entitlements that can generate resources to call attention needs capabilities. Sen (1978) concludes understand the absolute poverty level of deprivation that threatens the maintenance of mere physical existence and result in manifestations of starvation, malnutrition and visible hardship without having to inquire first an overview on. Consequently, the idea of relative poverty complements and does not replace the absolutist approach to poverty or extreme poverty. Relative poverty comes amid feelings of having less as soon as they have others, that is, according to the average obtained compared with 
others; while absolute poverty is achieved in extreme limitation of material resources starting with food.

Food analyzed capacities and poverty-through the income necessary to meet a CBA adding health services, education and the generation of resources that benefit the perceived- income, wealth LP is generated and the results are presented in Mexico in Figure \# 4.

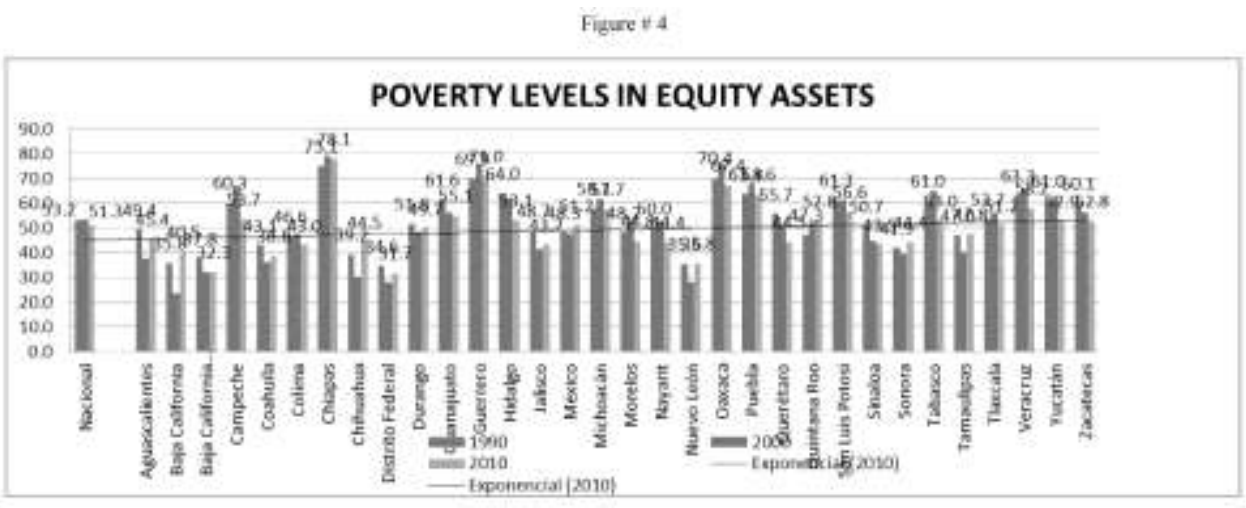

Data Source: Prepared by the INEGI database (1990-2014)

According to the above, reduce the poverty level of heritage is the means by which they fail to develop a system of organization and promotion of individual conditions that reduce the chances of future attention to poverty. However, asset poverty reduction measured by access to goods conditions to reduce social vulnerabilities in Mexico has decreased not significantly. This means that the rate of decline has not been important because from 1990 to 2010 such national level only declined $1.9 \%$. Representing that in the context of free market growth opportunities in the regional contact to promote the social status of the population in poverty has not been significant.

\section{HUMAN DEVELOPMENT IN MEXICO}

For the United Nations Development Programme (UNDP), the basic objective of development is to enlarge human freedoms in a process where they can expand personal skills all while expanding the choices available to people to live a full and creative life "(UNDP, 2004, 127). Therefore, UNDP has identified the context of Municipalities and the Human Development Index (HDI) reached.

In 2010, Mexico ranks as a country of high human development with an HDI of 0.739. At the state level, on the one hand, the Federal District (0.831), Nuevo Leon (0.790) and Baja California Sur (0.785) were the states with the highest level of development. On the other hand, Chiapas (0.647), Oaxaca (0.666) and Guerrero (0.673) are located in the last three positions of national law. The difference between extremes indicates that the Mexico City, obtains an HDI 28.4\% higher than that of Chiapas (UNDP, 2012). See Figure \# 5. 


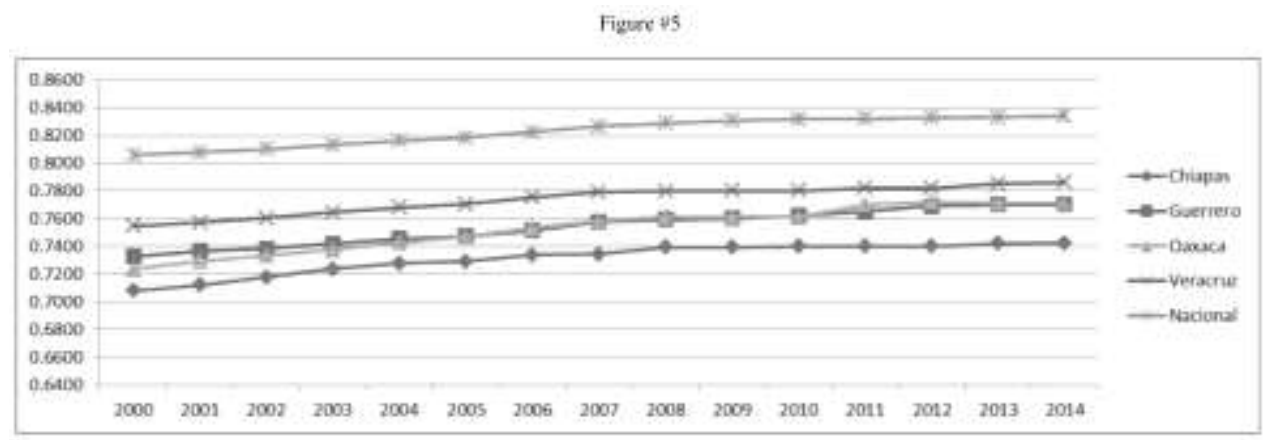

Data Source: Prepared by the INEGI database (1990-2014)

Before the concept of human development, the states where most progress in this area is achieved, can be related to the way in which exploit the available alternatives. That is, a basic understanding of the concept of poverty and its relationship to human development, it is possible to recognize conditions that exist between regions of Mexico where different ways to get benefits are achieved. That is, generators of poverty reduction; achieving positive results to exploit the economic and institutional conditions, ways of generating opportunities and productivity growth.

Although in recent years the national HDI has surpassed the current conditions intone, approach contrary to what the data displayed on the current poverty levels in Mexico there is a divorce between the levels of food poverty, skills and heritage generally. Food poverty as a condition of extreme deprivation in has remained. This suggests that although the HDI indicators show steady improvement, does not exceed the conditions of lack and scarcity.

\section{CONCLUSIONS}

Study the level of deprivation among the population as a means to study the existing poverty in the population, it means to do so from different approaches. First, in accordance with the approach that considers poverty as a condition obtained from the lack of minimum resources to meet needs such as food inalienable poverty; and secondly, from assets held expressing inequality compared to what others fail and at the same time.

The phenomenon of poverty is the level of deprivation that prevent the generation of assets, possessions and rights considered converted into assets. Therefore, absolute poverty -of Sen 1978, replaces the concept of poverty brought the classical school, referring to the conditions of lack of goods that are inalienable and materially necessary. Such as those that threaten the physical existence and breaking development of new assets in order to meet other needs or capabilities. While relative poverty is a particular situation perceived and thought structures have more or less over others.

According to the present conditions of production growth and opportunity in the Mexican context, the number of poor has remained. In the case of results obtained through poverty indicators divided into food, capacities and assets. As such, the level of growth in activities based on development opportunities under continuous shortage still limited.

However, despite poverty have been reduced in their official indicators, the number of poor is maintained in the states of Mexico. Providing an opportunity to develop new 
studies, to raise the new reality of the poor under identified conditions existing 2014 environment, so, to consider other ways of identifying the poor under a raised reality and justify development progress human as complementary ways not dissimilar within representing the current conditions in poverty.

\section{REFERENCES}

Gonzalez M.O y Menenes A. B. (2014). "Las líneas de pobreza en México: ¿un valor de bienestar en México?", publicado en Revista Ciencia Administrativa http://www.uv.mx/iiesca/files/2014/12/13CA201402.pdf

González M.O. Ruiz J. y Hernandez R. G.E. (2010) "La pobreza y los cambios en el gasto destinado a bienes elementales: el caso de México en el 2002 y 2008" en http://www.eumed.net/rev/tecsistecatl.

Hernández-Laos E. (2010). Crecimiento, distribución y pobreza, en Aparicio R., V. Villarespe y C. Urzúa (coords.) Pobreza en México: magnitud y perfiles, México: CONEVAL, UNAM e ITESM.

INEGI Instituto Nacional de Estadística y Geografía (2008). Encuesta Nacional de ingresos y gastos de los hogares (ENIGH). Recuperado el 23 de febrero del 2011 de www.inegi.gob.mx.

ENIGH Encuesta Nacional de Ingresos y Gasto de los hogares (2000). Recuperado el 15 de marzo del 2009 de www.inegi.org.mx/prod_serv/contenidos/.../enigh/.../ENIGH_2000.pdf

ENIGH Encuesta Nacional de Ingresos y Gasto de los hogares (2002). Recuperado el 15 de marzo del 2009 de www.inegi.org.mx/prod_serv/contenidos/.../enigh/.../ENIGH_2002.pdf

ENIGH Encuesta Nacional de Ingresos y Gasto de los hogares (2004). Recuperado el 15 de marzo del 2009 de www.inegi.org.mx/prod_serv/contenidos/.../enigh/.../ENIGH_2004.pdf

ENIGH Encuesta Nacional de Ingresos y Gasto de los hogares (2005). Recuperado el 15 de marzo del 2009 de www.inegi.org.mx/prod_serv/contenidos/.../enigh/.../ENIGH_2005.pdf

ENIGH Encuesta Nacional de Ingresos y Gasto de los hogares (2006). Recuperado el 15 de marzo del 2009 de www.inegi.org.mx/prod_serv/contenidos/.../enigh/.../ENIGH_2006.pdf ENIGH Encuesta Nacional de Ingresos y Gasto de los hogares (2000). Recuperado el 15 de marzo del 2009 de www.inegi.org.mx/prod_serv/contenidos/.../enigh/.../ENIGH_2008.pdf

ENIGH Encuesta Nacional de Ingresos y Gasto de los hogares (2002). Recuperado el 15 de marzo del 2009 de www.inegi.org.mx/prod_serv/contenidos/...enigh/.../ENIGH_2010.pdf

ENIGH Encuesta Nacional de Ingresos y Gasto de los hogares (2004). Recuperado el 15 de marzo del 2009 de www.inegi.org.mx/prod_serv/contenidos/...enigh/.../ENIGH_2012.pdf 
Journal of Social Sciences (COES\&RJ-JSS), 5(1), pp. 1-8

ENIGH Encuesta Nacional de Ingresos y Gasto de los hogares (2005). Recuperado el 15 de marzo del 2009 de www.inegi.org.mx/prod_serv/contenidos/.../enigh/.../ENIGH_2014.pdf

Maslow, A. H. (1943). A Theory of Human Motivation. Originally Published in Psychological Review, 50, 370-396.

Parker, S. (2007). Evaluación del impacto de Oportunidades 2001-2006. Serie de documentos de investigación. México: SEDESOL.

PNUD Comisión Nacional para el Desarrollo de los Pueblos Indígenas-Programa de las Naciones Unidas para el Desarrollo. Indicadores socioeconómicos de los pueblos indígenas para el 2007. Recuperado el 12 de abril de 2009. Disponible en: http://www.cdi.gob.mx/index.php?id_seccion=91 México.

Parker, S. \& McGinnis, L. (2001). Children and youth unit, development network. Washington, D.C.: The World Bank. 2001.

Sen, A. (1978). Three notes of concept of poberty, Documento de trabajo de investigación del Programa Mundial del Empleo, WEP22-239 ILO, Genova. pp.133.

Sen, A. (1992). Inequality Reexamined. UK: Oxford: Clarenton Press.

Sen, A. (2000). Desarrollo como Libertad. España: Editorial Planeta p. 28.

Townsend, P. (1979). Poverty in the United Kingdom. Harmoddsworth, Gran Bretaña: Penguin. 